\title{
PEWARISAN NILAI-NILAI KEARIFAN LOKAL UNTUK MEMPROTEKSI MASYARAKAT BALI DARI DAMPAK KEMAJUAN TEKNOLOGI
}

\author{
Ni Luh Ketut Sukarniti \\ Fakultas Ilmu Sosial dan Ilmu Politik Universitas Mahendradatta - Denpasar
}

\begin{abstract}
Abstrak-Pentingnya pewarisan nilai-nilai kearifan lokal bagi masyarakat Bali, selain untuk menghadapi berbagai dampak negatif perubahan sosial yang diabaikan teknologi.Gejala yang dialami masyarakat Bali kini adalah perubahan sosial budaya yang sangat mendasar.Akselerasi informasi gelombang teknologi membawa perubahan cukup signifikan pada masyarakat Bali, baik pada tataran surface structure (sikap dan pola-pola perilaku) dan deepstructure (sistem nilai,pandangan hidup, filsafat dan keyakinan).Perubahan terjadi karena kontak budaya antar masyarakat yang dimaknai adanya dialektika nilai-nilai baru dengan nilai-nilai lama yang saling mendominasi, memungkinkan terjadinya homoginesis, dan neoliberalisasi pada seluruh aspek kehidupan termasuk nilai-nilai budaya lokal yang selama ini menjadi pegangan masyarakat Bali. Kondisi ini menimbulkan spit dan kegamangan nilai, karena masyarakat Bali lebih menggunakan nilai modern dengan memarginalkan nilai transcendetal. Akibatnya terjadi berbagai bentuk penyimpangan nilai moral yang tercemin dalam corak, gaya, dan pola hidup masyarakat. Oleh karenanya penguatan dan pewarisan nilai-nilai kearifan lokal Bali perlu dilakukan secara intensif pada generasi muda Bali.
\end{abstract}

\section{Kata Kunci: Bali, Teknologi Modern, Nilai-Nilai Kearifan Lokal, Perubahan Sosial}

Abstract- The importance of maintaining local wisdom for Balinese people in order to face various negative impacts of social changes brought about by .Technology The symptom, which is basically felt by the Balinese today, is the fundamental socio-cultural change. The acceleration of the information coming along with the wave of technology has been significantly experienced by the Balinese, both at the level of the "surface structure" (the attitudes and the pattern of 
behavior) and at the level of the "deep structure" (the value system, the life view, the philosophy, and the belief). The change is due to the culture contacts between countries in which there are dialectic fight between the contemporary values and those of the traditional where one tries to take the domination of another. Here, the hegemony and the neoliberal views are possibly coming and breaking all the aspects of life, including the values of the local culture ever obeyed firmly by the Balinese society. This condition leads to a spit and uncertain values situation because the people give more attention and respect to the modern values and marginalize the transcendental values. This is resulting in various violations of the moral values reflected by the feature, the style, and the life pattern of the society to occur. Therefore, reinforcement and inheritance of Balineselocal wisdom have to be conducted intensively to the Balinese younger generation.

\section{Keywords: Bali, circle of the modern technology, values of the local wisdom, social change}

\section{Pendahuluan}

Gejala yang dialami masyarakat Bali kini adalah perubahan sosial budaya yang sangat mendasar. Akselerasi informasi gelombang teknologi membawa perubahan cukup signifikan pada masyarakat Bali, baik pada tataran surface structure (sikap dan pola-pola perilaku) dan deep structure (sistem nilai, pandangan hidup, filsafat dan keyakinan). Perubahan terjadi karena kontak budaya-budaya antar negara yangdimaknai adanya dialektika nilai-nilai baru dengan nilai-nilai lama yang saling mendominasi, yang memungkinkan terjadi homogenisasi dan neoliberalisasi pada seluruh aspek-aspek kehidupan termasuk nilai-nilai budaya lokal yang selama ini menjadi pegangan masyarakat Bali. Kondisi ini menimbulkan spit dan kegamangan nilai sebab masyarakat Bali lebih mengagungkan nilai-nilai modern,secara tidak langsung memarginalkan nilai transcendental. Akibatnya terjadi berbagai bentuk penyimpangan nilai-nilai moral yang tercermin dalam corak, gaya dan pola hidup masyarakat.

Oleh sebab itu, perlu ada penguatan dan pewarisan nilai kearifan lokal Bali, perlu juga dilakukan secara intensif pada generasi muda Bali.Gejala mendasar yang dirasakan oleh masyarakat Bali dewasa ini adalah perubahan sosial budaya yang sangat cepat.Perubahan sosial budaya terjadi dikarenakanadanya kontak budaya antar 
Negara. Kontak budaya dapat dimaknai sebagai pertemuan antara nilai-nilai baru dan nilai-nilai lama, yang mana saling mendominasi dan sangat berpengaruh dalam tataran surface structure, yakni pada sikap dan pola pola perilaku serta di dalam tataran deep structure, yaitu pada perubahan sistem nilai, pandangan hidup, filsafat, dan keyakinan. Intinya, perubahan masyarakat di Bali terjadi karena gelombang modernisasi dan teknologi yang telah memperkenalkan nilai baru dalam lingkungan tradisi Bali.Pesatnya kontak sosial-budaya antar provinsi dan negara terjadi karena kemajuan ilmu pengetahuan dan teknologi (IPTEK) ditandai dengan kian mutakhirnya media Informasi dan Teknologi Komunikasi (Information and Communicati on Technology).

Akselerasi tentang informasi gelombang teknologi telah menyebabkan dunia seakanakan menyatu menjadi satu kampung global(global village) dan tersatukannya budaya global dengan berasaskan pada nilainilai liberalistik-kapitalistik. Dengan begitu, tidak menutup kemungkinan terjadihomogenisasi (penyeragaman budaya) dan neoliberalisasi yang merasuk dalam seluruh lini kehidupan termasuk dalam praktek pendidikan.Hal ini berarti bahwa perubahan pada tataran nilai pada masyarakat Bali tidak dapat terelakkan.Apadurai (dalam Ritzer 2007:598) yang menggambarkan, bahwa perubahan nilai terjadi karena pengaruh;

(1) perpindahan orang (ethnoscape)

(2) media informasi (mediascape)

(3) yang dibawa atau yang dapat dilihat (technocape)

(4) terjadinya aliran kepemilikan modal (financesscape)

(5) ideologi-ideologi (ideoscapes) baik yang dibawa, diinformasikan maupun yang dapatdiadopsi.

Kondisi ini membawa konsekuensi yang sangat mendasar bagi kehidupan dan upaya mempertahankan kemurnian adat-istiadat dan nilai-nilai budaya lokal Bali.Teknologi menimbulkan pergulatan antara nilai budaya lokal dan nilai budaya global (modern) yang semakin tinggi intensitasnya.Sementara itu, dipahami bahwa nilai modern tidak selalu membawakan kebaikan bagi pengembangan nilai-nilai budaya lokal.

Croch (dalam Nesta, 1998) seorang pemerhati kebudayaan Bali dalam disertasinya memaparkan tentang konflik sosio-kultural yang terjadi di kalangan masyarakat khususnya masyarakat Bali Timur.Dikatakannya, bahwa secara empiris masyarakat Bali di bagian Timur mengalami degradasi nilai sosio-kultural yang disinyalir 
disebabkan karena pengembangan industri pariwisata.Dalam industri pariwisata terjadi "gesekan budaya", "pertukaran budaya" atau "adopsi budaya". Jika budaya yang diadopsi oleh masyarakat di Bali tidak sesuai budaya lokal Bali, maka akan terjadi persilangan budaya. Di dalam kondisi semacam ini, bisa terjadi pertahanan nilai etika dan budaya lokal yang menjadi pegangan masyarakat Bali akan semakin tergoyahkan, nilai tradisi masyarakat Bali yang ramah, lembut dan santun bisa tergilas oleh nilai-nilai baru yang bersandar dan berlindung kepada kebebasan mengatasnamakan hak asasi. Pertukaran informasi termasuk nilai antar bangsa yang berlangsung cepat dan dipenuhidinamika, mendorong terjadinya proses perpaduan nilai, kekaburan nilai, bahkan terkikisnya nilai-nilai asli yang sebelumnya sakral dan menjadi identitas suatu bangsa (Fukuyam, 1999). Ketika nilai-nilai teknologi diagungagungkan oleh para pendukungnya, maka

\section{Pembahasan}

\section{Keunikan Bali}

Bali memang menarik dan unik. Selain merupakan salah satu ikon kebanggaan Indonesia yang telah mendatangkan banyak wisatawan dan devisa bagi Indonesia karena lingkungan alam dan budayanya, menurut Triguna (2011:ix). Bali juga sebagai lokus saat itulah terjadi proses penggiringan nilainilai budaya tradisional masyarakat yang pada akhirnya mengakibatkan terjadinya split dan kegamangan nilai (Sauri, 2006). Kegamangan nilai ini juga sangat dirasakan dan dialami sebagian besar masyarakat Bali.Kegamangan nilai yang dialami masyarakat dewasa ini terjadi karena sisi negatif modernisasi dengan lebih mengutamakan kemampuan akal, dengan memarginalkan peran nilai-nilai transendental serta tunduk pada paham individualisme, materialisme,dan kapitalisme. Akibatnya, terjadi berbagai bentuk penyimpangan nilai moral yang tercermin dalam corak, gaya, dan pola hidup masyarakat. Fenomena menguatnya corak dan gaya hidup masyarakat yang hedonis cukup mengkhawatirkan bagi pelestarian nilai-nilai lokal dan memberikan dampak negatif terhadap jati diri orang Bali.

kehidupan yang unik memiliki banyak cerita yang dinamis sebagai pola kehidupan yang humanis-religius.Keunikan budaya Bali dilandasi oleh nilai-nilai yang bersumber pada ajaran agama Hindu.Masyarakat Bali mengakui adanya oposisi biner yang komplementer dalam konsep rwa-bhineda yang ditentukan oleh ruang (desa), waktu 
(kala), dan kondisi riil di lapangan (patra).Konsep desa, kala, patra ini menyebabkankebudayaan Bali bersifat fleksibel dan juga selektif dalam menerima dan mengadopsi pengaruh budaya luar. Budaya Bali juga memiliki identitas yang jelas yaitu budaya ekspresif yang termanifestasi secara konfiguratif yang mencakup nilai-nilai dasar yang dominan seperti nilai religius, nilai estetika, nilai solidaritas, nilai harmonis,dan nilai keseimbangan (Geriya 2000:129) yang tercermin dalam kearifan lokalnya. Clifford Geertz (1980) misalnya, dalam bukunya Negara, The Theatre State in Nineteenth Century Bali membahas tentang subak secara mendalam dan sistematis, yang sampai pada kesimpulan bahwa di seluruh dunia tidak ada organisasi sosial pengairan yang seefektif subak. Dalam kaitan dengan pembentukan karakter dilihat dari sisi fungsi nilai membentuk "isi" manusia, Geertz (dalam Triguna, 2011:84) juga pernah menulis tentang pola asuh orang Bali yang menurutnya model pola asuh orang tua telah membentukan karakter orang Bali itu secara keseluruhan. Demikian juga dengan V.E. Korn (1938) menuangkan kekagumannya tentang orang Bali dalam bukunya Het Adatrecht van Bali (Hukum Adat Bali). Dikatakan bahwa betapa orang Bali piawai dalam membuat saluran-saluran air di bawah tanah (bahasa Balinya: aungan), bahkan Korn menyebut bahwa mereka sebagai para insinyur Bali. Tidak ketinggalan, dibidang pengobatan tradisional (usada-Bali) menjadi daya tarik ilmuan kedokteran berkebangsaan Jerman, seperti Wolfgang Weck. Rakyat di Bali disebutkan bahwa tata cara pengobatan tradisonal Bali memberi sumbangan yang penting bagi metode pengobatan dalam ilmu kedokteran modern.Gambaran di atas, menunjukkan bahwa ada landasan yang kuat dan segi-segi positif tentang kemampuan orang Bali dengan kebudayaannya yang masih bersifat tradisional. Akan tetapi, dengan banyaknya wisatawan dengan membawa kultur mereka masing-masing, mulai menggoyahkan fondasi yang dibangun semenjak awal. Dapat dikatakan masyarakat Bali kini ada dalam pusaran ideologi modern akibat gelombang teknologi.

Tidak semua nilai-nilai budaya tersebut dapat hidup dan berkembang dengan baik karena terdesak kuatnya arus modernisasi dan teknologi.Hal tersebut disebabkan oleh kurangnya pemahaman masyarakat di Bali tentang hakekat dan pentingnya peranan budaya lokal Bali menyangkut adat, tradisi dan nilai agama Hindu yang menjiwainya. Akibatnya, banyak generasi muda Bali yang melupakan tradisi dan adat budaya Bali yang 
telah dibangun berabad-abad lamanya oleh nenek moyang orang Bali. Mengingat lingkungan yang terus berubah, yang mana perubahan itu tidak mungkin bisa terelakkan atau dihindari, maka tantangan utama yang dihadapi masyarakat Bali ke depan adalah meningkatkan kemampuan demi beradaptasi dengan perubahan dan dinamika (Bennet 1976: 257). Menurut Geertz (1980), lembaga tradisional seperti Desa Adat dengan awigawig-nya dianggap sebagai benteng terakhir dari ketahanan budaya Bali. Jika masyarakat

\section{Bali dalam Pusaran Ideologi Modern}

Kenyataan bahwa orang Bali belakangan cenderung mengadopsi kebudayaan modern (yang kemungkinan saja dinilai lebih praktis dibandingkanbudaya lokal). Di sisi lain, orang Bali berada pada persimpangan jalan karena mereka sedang menggiatkan Desa Adat (Desa Pakraman). Dengan kata lain, orang Bali pun dihadapkan pada fenomena paradoks, yakni berdiri pada pijakan yang berbeda. Kaki kanan terikat pada kekuatan tradisi, sedangkan kaki kiri menganut sistem nilai dari luar (nilai-nilai modern). Sentuhan dari budaya luar ini menyebabkan terjadinya ketidakseimbangan, sehingga masyarakat di Bali kehilangan orientasi (disorientasi) dan dislokasi hampir di setiap aspek kehidupan (Ardika, 2004a:1).
Bali menganggap caradalam penyesuaian yang dilakukan sebelumnya kurang cocok, misalnya sebagaimana yang telah diatur awig-awig, maka cara itu harus disesuaikan dengan cara yang dianggap lebih cocok atau awig-awig yang dimiliki mengakomodasi hal-hal baru dengan tetap berpegang pada nilai-nilai kearifan lokal. Dalam keadaan ini, pendidikan tentu memegang peranan penting di dalam mentrasformasi nilai-nilai budaya kepada generasi muda Bali.

Kehidupan modern akibat teknologi telah menimbulkan pergulatan antara nilainilai budaya lokal dengan budaya global pada masyarakat Bali. Sistem budaya lokal dengan kearifan lokalnya yang selama ini digunakan sebagai acuan pembentukan karakter oleh masyarakat Bali tidak jarang mengalami perubahan karena pengaruh nilai-nilai budaya global terutama karena kemajuan teknologi informasi yang semakin mempercepat proses perubahan tersebut. Berkembang pesatnya kemajuan teknologi di satu sisi mempermudah bagi kehidupan masyarakat Bali, akan tetapi di sisi lain menjadi beban terutama karena adanya sejumlah nilai-nilai ikutan dari teknologi yang membahayakan masyarakat khususnya generasi muda, yakni nilai-nilai sekular,pragmatis dan positivis. Nilai yang 
mapan selama ini telah mengalami perubahan yang pada saat gilirannya menimbulkan keresahan psikologis dan krisis identitas di banyak kalangan masyarakat Bali (Ardika,2004b:1).

Intinya, proses teknologi telah melahirkan diferensiasi yang meluas, yang tampak dari proses pembentukan gaya hidup dan identitas masyarakat Bali (Wolf, 2007:16).McKean (dalam Geriya 2000), menggambarkan bahwa Bali sesungguhnya sudah sangat terkenal sebagai pulau yang sangat tradisional akan tetapi kenyataannya Bali juga menjadi pulau yang sangat modern jika dibandingkan dengan wilayah-wilayah lainnya di Indonesia. Bali kini telah kena pengaruh Teknologi yang dicirikan dengan perpindahan orang, pengaruh teknologi, media informasi, pengaruh ideologi dan sebagainya.

Namun demikian, menurut Picard (2006), orang Bali telah memperlihatkan bakat istimewa dalam menyerap secara selektif pengaruh-pengaruh luar dengan hanya memilih unsur-unsur yang cocok dengan nilai yang ada pada mereka, yang selanjutnya dipadukan dengan selaras dalam sistem budaya mereka. Hasilnya bukan merupakan pelapisan strata budaya yang terpisah-pisah, melainkan suatu perpaduan yang orisinal dari benda-benda, citra dari praktek-praktek dan kepercayaan yang meskipun berbeda asalnya, namun lambat laun mengambil wujud menjadi sesuatu yang bersifat khas Bali.

Oleh karena itu, setiap orang yang pengetahuannya telah tersentuh oleh nilainilai baru, akan mencoba memberi makna baru bagi tatanan yang ada sebelumnya, tidak terkecuali pada hal-hal yang bersifat normatif. Bagus (1995) juga menegaskan, bahwa meskipun masyarakat di Bali telah mengalami "pergesekan budaya" yang datang dari timur dan barat, sehingga menimbulkan adanya perubahan-perubahan, namun pada hakekatnya perubahan yang ditimbulkan akibat pertemuan budaya tersebut belum begitu berarti, karena masyarakat Bali masih bercorak kolektif, komunal dan ritualistik. Namun demikian, seiring dengan makin kuatnya terpaan konsumerisme dan materialisme, kini perilaku orang Bali juga sudah menjadi semakin individualistis, asosial, bahkan menunjukkan sifat-sifat hedonis pada sebagian masyarakat. Menghadapi kondisi ini menjadi sebuah keniscayaan bagi para orang tua dan para pendidik formal lainnya mengangkat dan menggunakan nilai-nilai kearifan lokal Bali sebagai rujukan dalam pendidikan guna membentuk karakter manusia Bali.Diyakini, bahwa nilai 
termasuk nilai budaya merupakan sesuatu yang dianggap paling berharga dalam kehidupan masyarakat sebagai pedoman hidup yang memungkinkan setiap orang mencapai jagadhita (Triguna, 2011).

Nilai yang dianut tidak semata-mata sebagai pedoman hidup, tetapi juga membentuk karakter manusianya.Dalam fungsinya sebagai pedoman hidup, nilai menjadi batas-batas (boundary) terhadap nilai-nilai yang boleh dan tidak boleh dilakukan.Nilai juga menjadi semacam referensi mengenai kebenaran, kepatutan dan kebaikan.Jadi nilai berfungsi sebagai panduan dalam membantu manusia menjadi lebih tertib dan berbudaya. Dalam konteks praktek pendidikan, Zuchdi (2008) menyebutkan bahwa pendidikan bukan hanya sekedar menumbuhkan dan mengembangkan keseluruhan aspek kemanusiaan tanpa diikat oleh nilai, akan tetapi nilai itu merupakan pengikat dan pengaruh proses pertumbuhan dan perkembangan manusia. Agar standar nilai

\section{Strategi Pewarisan Nilai Kearifan}

\section{Lokal dalam Membentuk Karakter}

Penanganan dampak dominasi budaya global terhadap budaya lokal salah satunya dapat dilakukan melalui pengembangan kualitas sumber daya manusia Bali (SDM yang dipegang teguh selama ini oleh masyarakat Bali lambat laun tidak rapuh, maka rujukan etika yang dikembangkan dalam pendidikan tidak cukup hanya berdasarkan kepada nilai moral masyaraat Bali, akan tetapi harus berdasarkan nilai transendental yang bersumber dari agama, adat- istiadat dan tradisi nilai-nilai lokal. Pedoman nilai pada masyarakat Bali banyak terdapat pada kearifan-kearifan lokal yang dijiwai oleh agama Hindu.Tradisi budaya masyarakat Bali mempunyai banyak potensi kearifan lokal yang dapat digunakan oleh masyarakat Bali sebagai rambu-rambu atau pedoman dalam pendidikan dan dalam menjalani kehidupannya. Oleh karena itu, menjadi tugas bersama terutama kalangan pendidik (formal dan informal) mengangkat nilai-nilai lokal Bali yang terpendam untuk diperkenalkan dan ditanamkan pada generasi muda Bali dalam membentuk karakternya sebagai manusia sosial, religius, estetik, ekonomik dan adaptip terhadap lingkungan.

Bali), perluasan akses, dan relevansi pendidikan berbasis budaya dan kearifan lokal Bali. Upaya ini diharapkan dapat semakin mengenalkan dan meningkatkan kecintaan masyarakat Bali terhadap budaya Bali sekaligus meningkatkan kualitas dan 
daya saing masyarakat Bali. Kendati teknologi menciptakan banyak kesempatanuntuk berbagi pengetahuan, teknologi, nilai-nilai sosial, dan normanorma perilaku yang mempromosikan perkembangan individu, organisasi dan masyarakat, nilai-nilai lokal tetap harus menjadi basis penyaring. Agar masyarakat Bali mampu mempertahankan identitasnya tanpa harus terseret terlalu larut dalam arus teknologi, salah satunya adalah dengan memiliki ketahanan budaya lokal yang tinggi.

Sedyawati (2007:37) memaknai ketahanan budaya sebagai kemampuan sebuah kebudayaan untuk mempertahankan jati dirinya, tidak dengan menolak segala unsur asing dari luarnya, melainkan dengan menyaring, memilih dan jika perlu memodifikasi unsur-unsur budaya luar sehingga tetap sesuai dengan karakter dan citra Bangsa.

Modernisasi teknologi sekaligus untuk membentuk karakter. Setiap wilayah tentu memiliki budaya sendiri dengan berbagai kearifan di dalamnya. Bahkan sekolah atau lembaga pendidikan formal yang ada di wilayah tersebut menjadikan kearifan lokal wilayah tersebut sebagai rujukan untuk membentuk kultur sekolah, agar peserta didik tidak terasing dari budaya yang melingkupinya. Secara filosofis, nilai kehidupan yang dianut oleh masyarakat akan berpengaruh terhadap jalannya proses pendidikan. Contoh, dalam masyarakat Bali dasar keyakinannya adalah agama Hindu, yaitu Panca Sradha dan filsafat-filsafat kehidupan lainnya, seperti Tri Rna, Tri Guru, Tri Pramana,Tri Mandala, Catur Asrama, Catur Purus Artha dan lainnya yang akan dimanifestasikan dalam setiap langkah proses pendidikan, baik di sekolah, dalam keluarga maupun di masyarakat. Di samping nilai-nilai filosofis tersebut, tatanan praktek kehidupan sehari-hari seperti tat twam asi (saling asih), gotong royong menyama braya akan memberikan inspirasi pada praktekpraktek pendidikan.

Namun demikian, banyak nilai budaya dan orientasinya yang bisa menghambat dan bisa mendorong pendidikan. Bahkan, banyak pula nilai-nilai budaya yang dapat dimanfaatkan secara sadar dalam proses pendidikan. Sebagai bahan banding, di Jepang misalnya, "moral Ninomiya Kinjiro" merupakan nilai budaya yang dimanfaatkan praktek pendidikan untuk mengembangkan etos kerja masyarakat Jepang, sehingga orang-orang Jepang terkenal dengan keuletan dan budaya kerjanya yang tinggi (Zamroni, 2000). Dari contoh di atas, jelas tampak betapa pentingnya nilai-nilai 
budaya daerah (kearifan-kearifan lokal) untuk ditanamkan kepada peserta didik. Penemuan tentang nilai-nilai dan orientasi budaya daerah (setempat) yang memiliki nilai positif bagi praktek pendidikan, menjadi hal penting dalam upaya menangkal sisi negatif pengaruh global. Pendidikan di Indonesia harus berkaitan erat dengan falsafat dan budaya Bangsa. Surachmad (1986) memperingatkan "bahwa ilmu kependidikan yang tidak lahir dan tidak tumbuh dari bumi yang diabdinya tidak akan pernah mampu melahirkan potensi untuk menangani masalah yang tumbuh di bumi

\section{Penutup}

\section{Simpulan}

Tantangan terbesar yang dihadapi masyarakat Bali belakangan ini adalah kemampuan dalam menjaga, melestarikan dan mewariskan kearifan-kearifan lokal.Pewarisan nilai kearifan lokal dimaksudkan agar generasi muda Bali dapat memproteksi diri dari pengaruh negatif modernisasi akibat teknologi.Teknologi yang dicirikan oleh perpindahan orang, pengaruh teknologi, pengaruh media informasi, aliran uang dari negara kaya ke negara miskin dan pengaruh ideologi, sangat dirasakan masyarakat Bali. Sentuhan budaya global menyebabkan terjadinya ini”. Kesesuaian antara tujuan lembaga dengan falsafah, moral serta etika yang dianut dalam masyarakat, merupakan satu bentuk pertanggung-jawaban sekolah kepada masyarakat (Joni, 2003).

Karena itu nilai-nilai budaya daerah (Bali) perlu lebih banyak digali untuk dijadikan dasar pelaksanaan pendidikan, baik yang ada dalam susastra Hindu maupun tradisi yang hidup dan berkembang di masyarakat. Dengan demikian, masyarakat Bali akan "terbentengi" dari pengaruh negatif budaya global.

perubahan sosial-budaya dan tataran nilai pada masyarakat Bali. Modernisasi dan teknologi memperkenalkan nilai-nilai baru dalam lingkungan tradisi Bali. Sistem budaya lokal dengan kearifan lokalnya yang selama ini digunakan sebagai acuan pembentukan karakter masyarakat Bali tidak jarang mengalami perubahan karena pengaruh budaya global, yang dapat menimbulkan keresahan psikologis dan krisis identitas pada sebagian masyarakat Bali.Kegamangan nilai juga dialami masyarakat Bali modern karena lebih mengutamakan kemampuan akal dibanding dengan nilai-nilai transendental serta tunduk pada paham individualisme, materialisme 
dan kapitalisme yang berakibat terjadinya penyimpangan nilai moral yang tercermin di dalam corak, gaya, dan pola hidup masyarakat. Fenomena menguatnya corak dan gaya hidup hedonis mengkhawatirkan bagi pelestarian nilai-nilai budaya lokal. Oleh karena arus teknologi tidak dapat dihindari, maka dalam pewarisan nilai-nilai budaya Bali atau kearifan-kearifan lokal dengan serapan nilai global.

\section{Daftar Pustaka}

Ardika, I Wayan, 2004a. Kebudayaan Lokal, Multikultural, dan Politik Identitas dalam Refleksi hubungan Antaretnis antara Kearifan Lokal dengan Warga Cina di Bali. Fakultas Sastra, Universitas Udayana.

Ardika, I Wayan, 2004b.Potensi Kebudayaan Bali: Strategi Pengembangan dan Pemberdayaandalam Konteks Otonomi Daerah dan Kehidupan Modern yang Multikultural. Makalah. Dalam Seminar Internasional Kebudayaan Minangkabau dan Potensi Etnik dalam Paradigma Multikultural, pada Program Studi Bahasa, Sastra dan

\section{Saran-saran}

Pada jaman globalisasi ini masyarakat Bali termasuk generasi muda Bali dapat menjaga diri dari pengaruh negatif maupun pengaruh positif akibat dampak kemajuan teknologi. Sehingga generasi muda Bali bisa menjaga, melestarikan dan mewariskan nilai-nilai kearifan lokal Bali.

Budaya Minangkabau, Jurusan

Sastra Daerah Fakultas Sastra Universitas Andalas. 23-24 Agustus 2004. Di Aula Universitas Andalas.

Bagus, I Gusti Ngurah. 1995. Sumbangan Nilai Budaya Bali dalam Pembangunan Kebudayaan Nasional. Jakarta: Proyek Penelitian dan Pengkajian Kebudayaan Bali, Direktorat Jendral Kebudayaan Departeman Pendidikan dan Kebudayaan

Geertz, Clifford. 1980. Negara. The Theatre State in Nineteenth Century Bali. New Jersey: Princeton University Press.

Geriya.I Wayan.2000. Transformasi Kebudayaan Bali Memasuki Abad 
XXI. Denpasar: Perusahaan Daerah

Propinsi Bali, Unit Percetakan Bali.

Joni, T. Raka. 2003. “ Pemeliharaan Kultur Akademik Prana dalam Kehidupan Organisasi Perguruan Tinggi”. Makalah.Di-sampaikan dalam Seminar dalam rangka Dies Natalis III IKIP Negeri Singaraja, 3 Februari, di Aula IKIP Negeri Singaraja.

Korn, V.E.1972. Hukum Adat Waris di Bali. Translitor, I Gde Wayan Pangkat.Dari "Het Adatrecht van Bali”. 1938. Denpasar Fakultas Hukum\& Pengetahuan Masyarakat Universitas Udayana.

Nesta.1998. Masyarakat Bali dalam Kebalian yang Tersamarkan.Makalah. Denpasar: Dirjen Kebudayaan RI.

Picard, Michel. 2006. Bali: Pariwisata Budaya dan Budaya Pariwisata (Bali: Culture Tourism and Tourism Culture). Jakarta: Kepustakaan Populer Gramedia

Sedyawati, Edi. 2007. Keindonesian dalam Budaya. Jakarta: Wedatama Widya
Triguna, Ida Bagus Gde Yudha. 2011.

Mengapa Bali Unik?. Jakarta:

Pustaka Jurnal Keluarga.

Zamroni. 2000. Paradigma Pendidikan

Masa Depan. Yogyakarta: Bigraf

Publishing

Zuchdi, Darmiyati. 2008. Humanisasi Pendidikan: Menemukan Kembali Pendidikan yang Manusiawi. Jakarta: Bumi Aksara.

Sastra. 